\title{
Prevalence, Severity and Relationship of Anaemia with Immune Status and Use of Highly Active Antiretroviral Therapy among Human Immunodeficiency Virus-Infected Adults in South-eastern Nigeria
}

Chioma P. Nnamani, M.B.B.S., F.W.A.C.P., ${ }^{1,2}$, Nkiru N. Ezeama, M.B.B.S., M.P.H., F.W.A.C.P., ${ }^{1,3}$, Owulo Agada, M.B.B.S., F.W.A.C.P., F.M.C.F.M. ${ }^{2}$, Paul N. Obiegbu, M.B.B.S., F.W.A.C.P., F.M.C.G.P. ${ }^{2}$, Kenechi O. Nnamani, M.B.B.S. ${ }^{4}$

'Department of Community Medicine and Primary Health Care, Faculty of Medicine, Nnamdi Azikiwe University, Awka/Nnewi Campus, Nnewi, Anambra State, 435001, Nigeria.

${ }^{2}$ Department of Family Medicine, Nnamdi Azikiwe University Teaching Hospital, Nnewi, Anambra State, 435001, Nigeria. ${ }^{3}$ Department of Community Medicine, Nnamdi Azikiwe University Teaching Hospital, Nnewi, Anambra State, 435001, Nigeria. ${ }^{4}$ Department of Paediatrics, Nnamdi Azikiwe University Teaching Hospital Nnewi, Anambra State, 435001, Nigeria.

Received 16 July 2020 • Revised 29 October 2020 • Accepted 3 November 2020 • Published online 1 April 2021

Abstract:

Objective: Anaemia is a significant complication of human immunodeficiency infection, causing life-threatening symptoms and impairing quality of life. This study aimed to assess the prevalence, severity and associations of anaemia, with cluster of differentiation 4 (CD4+) cell count and use of highly active antiretroviral therapy (HAART), in human immunodeficiency virus-infected patients.

Material and Methods: Haemoglobin concentration, CD4+ count, HAART use and other factors were assessed in 372 , adult HIV-infected out-patients; enrolled at a tertiary hospital in South-Eastern Nigeria. Anaemia was defined according to World Health Organisation criteria. Independent predictors were determined using bivariate analysis and enter method logistic regression analysis, at a $\mathrm{p}$-value $<0.050$.

Results: Prevalence of anaemia was $76.3 \%$ overall; $79.9 \%$ in females and $67.6 \%$ in males. Median CD4+ cell count was 609.50 (interquartile range 379) cells per microlitre (cells/ $\mu$ l). Females were more likely to be anaemic than males [odds ratio $(\mathrm{OR})=1.88$, 95\% confidence interval $(\mathrm{Cl}) 1.07$, 3.31; $\mathrm{p}$-value $=0.011$ ]. Furthermore, the odds of being anaemic were

Contact: Nkiru N. Ezeama, M.B.B.S., M.P.H., F.W.A.C.P.

Department of Community Medicine and Primary Health Care, Faculty of Medicine,

Nnamdi Azikiwe University, Awka/Nnewi Campus, Nnewi, Anambra State, 435001, Nigeria.

E-mail: nn.ezeama@unizik.edu.ng

This is an open access article under the CC BY-NC-ND license

(http://www.jhsmr.org/index.php/jhsmr/about/editorialPolicies\#openAccessPolicy). 
higher in participants 50 years or older (OR 3.79, 95\% Cl 1.36, 10.55; p-value=0.023). A CD4+ count <200 cells/ $\mu$ l. Not being on cotrimoxazole preventive therapy and a low monthly household income were associated with higher odds of anaemia. Tenofovir- and abacavir-based regimens were associated with lower odds of anaemia compared to zidovudine.

Conclusion: Gender and the age of patients were independent predictors of anaemia. Pre-treatment screening, and close follow-up monitoring for anaemia as well as increased access to less haematotoxic HAART regimens are needed.

Keywords: anaemia, CD4+ count, HAART, HIV care, HIV patients, Nigeria

\section{Introduction}

Anaemia refers to an insufficient number and oxygen-carrying capacity of red blood cells to meet the body's physiologic demands; often accompanied by diminished haemoglobin levels or altered red blood cell morphology. ${ }^{1,2}$ Human immunodeficiency virus (HIV) infection is a spectrum of disorders ranging from primary infection, through an asymptomatic infected state, to advanced disease characterized by opportunistic infections and neoplasms. ${ }^{3}$ Anaemia is the most common haematological abnormality in HIV-infected patients; even among those who are on highly active antiretroviral therapy (HAART), ${ }^{4}$ causing accelerated disease progression to acquired immunodeficiency syndrome (AIDS) and increased mortality. ${ }^{5,6}$ The pathogenesis of anaemia in HIV infected patients may involve four basic mechanisms: blood loss from opportunistic infections, decreased erythrocyte production, increased erythrocyte destruction and ineffective erythrocyte production from iron and other nutritional deficiencies. ${ }^{7,8}$

The risk of mortality in HIV infected individuals increases with the severity of anaemia, irrespective of differences in patient populations, treatment regimens and definitions of anaemia. ${ }^{9-11}$ The World Health Organisation (WHO) designated unexplained severe anaemia with haemoglobin values below 8.0 grams per deciliter $(\mathrm{g} / \mathrm{dL})$ as a HIV clinical stage III defining condition. ${ }^{12}$ Anaemia prevalence HIV-infected patients displays wide, global variations; ranging from $1.2 \%$ to $95.0 \%$ depending on the clinical setting. ${ }^{13,14}$ A prevalence of about $35.0 \%$ among HIV- infected patients in Europe and North America has been reported ${ }^{15}$, while among HIV/AIDS patients in sub-Saharan Africa, it ranges from $45.0 \%$ to $87.0 \% .{ }^{16}$ Additionally, it is highly prevalent in Nigeria, with regional variation ranging from $57.5 \%$ to $67.4 \%$. $^{17-20}$

Anaemia in HIV infected people is associated with depletion of cluster of differentiation 4 (CD4+) T-lymphocytes and decreased response to HAART, with more than $70.0 \%$ of anaemic HIV infected people requiring blood transfusions. ${ }^{20,21}$ CD4+ cell counts as low as $<200$ cells $/ \mu \mathrm{l}$ has been independently associated with an increased risk of anaemia. ${ }^{22}$ Although another study did however not find a significant association between CD4+ count and anaemia. ${ }^{23}$ HAART may ameliorate the effects of HIV-related anaemia in an indirect manner, by decreasing the HIV viral load and stimulating hematopoietic cell growth. However some antiretroviral drugs; such as nucleoside analogue, reverse transcriptase inhibitors; particularly zidovudine which may cause or worsen existing anaemia. ${ }^{17}$

Anaemia has an enormous impact on the quality of life of HIV infected patients. ${ }^{6,14,20}$ Treatment of HIV-related anaemia with HAART has several benefits, including the improvement in functional status and energy levels, reduced fatigue and overall improvement in the quality of life. ${ }^{11}$ This underscores the value of monitoring haemoglobin levels in HIV infected patients before and following HAART initiation, and makes the case for routine screening and treatment of anaemia in HIV patients on HAART. ${ }^{14}$ In view of this, this study aimed to assess the prevalence of anaemia and 
determine its relationship with CD4+ cell counts, and use of HAART in HIV infected patients assessing care in a tertiary health facility in south-eastern Nigeria.

\section{Material and Methods}

This study was conducted at Nnamdi Azikiwe University Teaching Hospital (NAUTH), a multi-specialty tertiary health facility located in Nnewi, a commercial city located $37 \mathrm{~km}$ from Awka; the capital city of Anambra state, South-Eastern Nigeria. The hospital provides comprehensive HIV treatment and care to all ages of HIV-infected individuals through its out-patient antiretroviral therapy (ART) clinics. The adult ART clinic sees approximately 2,200 patients per month, an average of 110 patients daily and consultations run every day; with the exception of Saturdays and Sundays.

Ethics approval was granted by the Nnamdi Azikiwe University Teaching Hospital Ethics Committee (NAUTH/ CS/66 NOL 9/96), and the study was conducted in accordance with the ethical standards of the committee and the Declaration of Helsinki.

This was a cross-sectional study, conducted from May, 2018 to July, 2019. Our study participants were adults aged 18 years and older, who had been confirmed HIVpositive by Western blot following rapid screening, using HIV STAT-PAK. Only individuals enrolled for care as outpatients at the Adult ART clinic NAUTH, Nnewi at the time of the study were included; irrespective of whether they were on HAART or not. However, we excluded hospitalised patients, patients who had received a blood transfusion within 3 months preceding the study, pregnant and lactating women, patients who had other known chronic diseases; such as, chronic kidney disease, sickle cell disease or thalassemia as well as critically ill patients. Employing the Cochran formula ${ }^{24}$, a minimum sample size of 337.6 was calculated, based on the standard normal deviate corresponding to the two-sided $95 \%$ confidence level $\left(Z_{1-\alpha}\right.$
=1.96), estimated prevalence of anaemia in HIV-infected patients in Nigeria of $67.4 \%{ }^{19}$, and a degree of precision of $5.0 \%$. Taking into consideration a possible non-response rate of at least $10.0 \%$, the sample size was adjusted to a final value of 376 participants.

Based on a monthly patient load of 2200 , study participants were recruited using a systematic random sampling method, at a sampling interval of 18 over a threemonth period. Using the clinic daily attendance register as the sampling frame, the first patient to be recruited every day was determined by balloting for a number between one and eighteen. Subsequently, every $18^{\text {th }}$ patient on the sampling frame was recruited. Six participants were recruited every day until the required sample size was reached. A total of 6,350, adult HIV infected patients visited the adult ART clinic during the $3-$ month recruitment period from $15^{\text {th }}$ of May to $18^{\text {th }}$ of August, 2017; out of which 376 study participants were enrolled.

Patients in the clinic waiting area were addressed each day on the purpose and benefits of the study, and those who met the inclusion criteria and agreed to participate provided written informed consent. A semi-structured questionnaire was used to collect demographic and clinical data from the participants, and from their medical records by trained research assistants. Participants were also physically examined for pallor, jaundice, respiratory rate, pulse rate and the findings were recorded.

Participants' weights were measured using an electronic scale (SECA 803). Before every measurement, zero calibration of the scale was done. Each participant was weighed wearing only light clothing and without shoes, and the measurement was recorded to the nearest 0.1 kilogram. Height was measured using a stadiometer (SECA 225). Participants were measured without shoes while standing upright with their head positioned in Frankfurt horizontal plane. They were asked to put their feet together, relax their shoulders, have their arms by their sides and their 
heels, buttocks, shoulder blades and back of the head against the vertical board of the stadiometer. With the headboard lowered to the top of the participant's head, the measurement was recorded to the nearest $0.1 \mathrm{~cm}$.

Blood samples were collected for determination of haemoglobin concentration and CD4+ count. The antecubital fossa of the right or left upper limb of each participant was aseptically cleaned using a cotton swab and methylated spirits. A total of five millilitres of venous blood was collected into a sterile vacutainer with Ethylene-Diamine-Tetra-Acetic acid anticoagulant. Two milliliters of blood was used for haemoglobin concentration and three milliliters for CD4+ cell count.

The cynamethaemoglobin method was used in determining haemoglobin concentration, and carried out in a spectrophotometer 20D (manufactured by Techmel and Techmel, The United States of America) at wavelength of 540 nanometres. Haemoglobin levels were calculated using the cyanmethaemoglobin standard curve. ${ }^{25}$ Quality control of the haemoglobin concentration results was ensured by daily testing of a haemoglobin standard, with a known concentration, and running the participants' tests only when the quality control check was successful. To further ensure validity of the results, the reading for each participant was repeated within 3 hours. The mean of both estimations, per sample was then calculated and taken as the accurate haemoglobin concentration of the participant.

The blood collected for CD4+ cell count was kept at room temperature and analysed within 6 hours of venepuncture using a Partec Gmbh 2011 CyFlow counter 2 (manufactured by Sysmex Company, Munster Germany). Internal quality control of the CyFlow counter was done by daily running of count check beads of a known concentration, to ensure that the laser was properly aligned and the analyser was functioning effectively.

Anaemia was defined according to $\mathrm{WHO}$ criteria as: haemoglobin $<13.0 \mathrm{~g} / \mathrm{dL}$ in males and $<12.0 \mathrm{~g} / \mathrm{dL}$ in females. This was further categorised as mild anaemia (11.0-12.9 g/dL in males and 11.0-11.9 g/dL in females); moderate anaemia (8.0-10.9 $\mathrm{g} / \mathrm{dL}$ in both males and females); and severe anaemia $(<8.0 \mathrm{~g} / \mathrm{dL}$ in both males and females). ${ }^{1}$ The CD4+ cell count was used as the measure of immune status and categorised into four: non-significant immunosuppression (>500 cells $/ \mu \mathrm{l}$ ), mild immunosuppression (350-499 cells/ $\mu \mathrm{l})$, advanced immunosuppression (200-349 cells/ $\mu \mathrm{l})$, and severe immunosuppression $(<200$ cells $/ \mu \mathrm{l}) .^{12}$ Definition of HAART regimens were in accordance with the Nigerian national guidelines for HIV prevention, treatment and care. ${ }^{26}$

Data collected was analysed using the Statistical Package for Social Sciences software version 23. The dependent variables were presence and severity of anaemia, while independent variables included duration of HAART use, class of HAART, CD4+ cell count, sociodemographic and clinical characteristics of the participants. Relevant percentages for categorical variables and mean, or median for continuous variables were calculated; significance of associations were determined with Pearson's chi-square $\left(X^{2}\right)$ test or Fisher's exact test, where appropriate for bivariate analysis and independent associations, with logistic regression analysis. Statistical significance was set at a p-value $<0.050$.

\section{Results}

Three hundred and seventy-two (372) HIV-infective people were surveyed using interviewer-administered questionnaires, which were all completed and returned without errors; giving a response rate of $100 \%$. Out of 376 participants, $268(71.3 \%)$ were females and 108 (28.7\%) were males. The age of the study participants ranged from 18 to 82 years, with a mean age of $45.5 \pm 10.1$ years (48 years for males and 44 years for females). More than half of them were married $(54.8 \%)$, while a substantial proportion were widowed (29.3\%). Across the measures 
of socioeconomic status, participants who had secondary level education made up the highest proportion (44.4\%). More than half $(51.1 \%)$ were self-employed and $26.9 \%$ had an average monthly household income of 18,000 Naira (or less); the national minimum wage at the time of the study, which is equivalent to approximately 50 United States dollars (Table 1).

Table 1 Sociodemographic characteristics of 376 adult human immunodeficiency virus positive patients receiving care at Nnamdi Azikiwe University Teaching Hospital Nnewi, South-Eastern Nigeria

\begin{tabular}{|c|c|c|}
\hline Variable & Number & $\%$ \\
\hline \multicolumn{3}{|l|}{ Age (years) } \\
\hline 18-30 & 20 & 5.3 \\
\hline $31-49$ & 221 & 58.8 \\
\hline$\geq 50$ & 135 & 35.9 \\
\hline Mean (S.D.) & $45.5(10.1)$ & \\
\hline \multicolumn{3}{|l|}{ Sex of the patient } \\
\hline Males & 108 & 28.7 \\
\hline Females & 268 & 71.3 \\
\hline \multicolumn{3}{|l|}{ Marital status } \\
\hline Never married & 37 & 9.8 \\
\hline Married & 206 & 54.8 \\
\hline Separated/divorced & 23 & 6.1 \\
\hline Widowed & 110 & 29.3 \\
\hline \multicolumn{3}{|l|}{ Educational level } \\
\hline No formal education & 16 & $4.3^{\prime}$ \\
\hline Primary education & 138 & 36.7 \\
\hline Secondary education & 167 & 44.4 \\
\hline Tertiary education & 55 & 14.6 \\
\hline \multicolumn{3}{|l|}{ Employment status } \\
\hline Full-time employee & 41 & 10.9 \\
\hline Part-time employee & 18 & 4.8 \\
\hline Self-employed & 192 & 51.1 \\
\hline Unemployed & 114 & 30.3 \\
\hline Retired & 11 & 2.9 \\
\hline \multicolumn{3}{|c|}{ Monthly household income (Naira) } \\
\hline$\leq 18,000$ & 101 & 26.9 \\
\hline$>18,000$ to $<75,000$ & 211 & 56.1 \\
\hline 75,000 to $<100,000$ & 22 & 5.9 \\
\hline$\geq 100,000$ & 42 & 11.2 \\
\hline
\end{tabular}

S.D.=standard deviation
Figure 1 shows that the dependent variable, anaemia was present in $287(76.3 \%)$ of the study participants. Overall, 121 (32.2\%) had mild anaemia, 158 (42.0\%) had moderate anaemia and $8(2.1 \%)$ participants had severe anaemia.

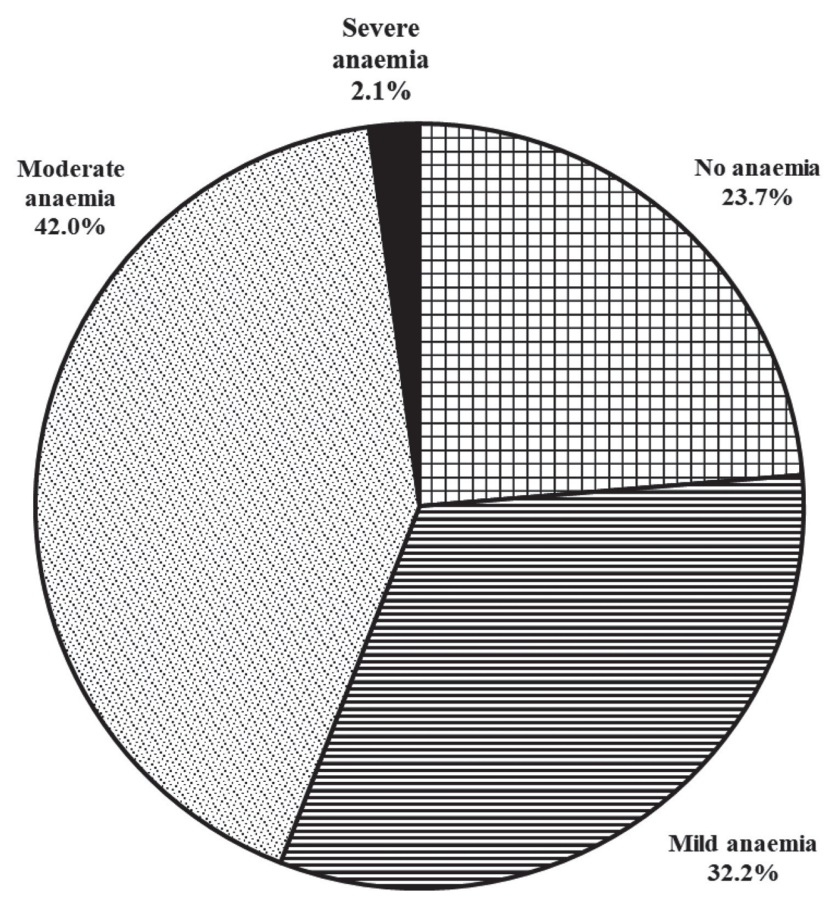

Figure 1 Prevalence and severity of anaemia in 376, adult human immunodeficiency virus positive patients receiving care at Nnamdi Azikiwe University Teaching Hospital Nnewi, South-Eastern Nigeria

Other clinical characteristics of the study participants are described in Table 2. Mean haemoglobin level in anaemic patients was 10.5 [standard deviation (S.D.) 1.3] $\mathrm{g} / \mathrm{dL}$ and in nonanaemic patients, 14.0 (S.D. 1.7) $\mathrm{g} /$ dL. Almost all the participants had commenced HAART $(98.9 \%)$; the majority had been on therapy for more than five years $(74.2 \%)$ and the most common regimen used was zidovudine-based (52.2\%). More than two-thirds (65.2\%) were not on cotrimoxazole preventive therapy (CPT). The minimum CD4+ count was 23 cells/ $\mu$ l, the maximum was 
2,108 cells/ $\mu \mathrm{l}$ and the median 610 (interquartile range was 434-813) cells/ $\mu$ l. Only 17 participants (4.5\%) had CD4+ counts of less than 200 cells/ $\mu$ l.

Table 2 Clinical characteristics and laboratory data of 376 , adult human immunodeficiency virus positive patients receiving care at Nnamdi Azikiwe University Teaching Hospital Nnewi, South-Eastern Nigeria

\begin{tabular}{|c|c|c|}
\hline Variable & Number & $\%$ \\
\hline \multicolumn{3}{|c|}{ Haemoglobin level, Mean \pm S.D. (g/dl) } \\
\hline Overall & \multicolumn{2}{|l|}{$11.3 \pm 2.1$} \\
\hline Anaemic patients & \multicolumn{2}{|l|}{$10.5 \pm 1.3$} \\
\hline Non-anaemic patients & \multicolumn{2}{|l|}{$14.0 \pm 1.7$} \\
\hline Females & \multicolumn{2}{|l|}{$10.9 \pm 1.8$} \\
\hline Males & \multicolumn{2}{|l|}{$12.4 \pm 2.3$} \\
\hline \multicolumn{3}{|l|}{ HAART status } \\
\hline HAART experienced & 372 & 98.9 \\
\hline HAART naïve & 4 & 1.1 \\
\hline \multicolumn{3}{|c|}{ Duration on HAART $(n=372)$} \\
\hline$\leq 1$ year & 19 & 5.1 \\
\hline$>1-5$ years & 77 & 20.7 \\
\hline$>5$ years & 276 & 74.2 \\
\hline \multicolumn{3}{|l|}{ HAART regimen } \\
\hline AZT/3TC/NVP & 194 & 52.2 \\
\hline TDF/3TC/EFV & 127 & 34.1 \\
\hline $\mathrm{ABC} / 3 \mathrm{TC} / \mathrm{EFV}$ & 10 & 2.7 \\
\hline Pl-based, second line & 41 & 11.0 \\
\hline \multicolumn{3}{|c|}{ On cotrimoxazole preventive therapy } \\
\hline Yes & 131 & 34.8 \\
\hline No & 245 & 65.2 \\
\hline \multicolumn{3}{|l|}{ CD4+ count (cells/ $\mu \mathrm{l})$} \\
\hline$<200$ & 17 & 4.5 \\
\hline $200-349$ & 45 & 12.0 \\
\hline $350-499$ & 64 & 17.0 \\
\hline$\geq 500$ & 250 & 66.5 \\
\hline Median (IQR) & \multicolumn{2}{|c|}{$610(434-813)$} \\
\hline \multicolumn{3}{|l|}{ Comorbidity } \\
\hline Yes & 71 & 18.9 \\
\hline No & 305 & 81.1 \\
\hline \multicolumn{3}{|l|}{ Body mass index } \\
\hline Underweight & 5 & 1.3 \\
\hline Normal & 159 & 42.3 \\
\hline Overweight & 125 & 33.2 \\
\hline Obese & 87 & 23.1 \\
\hline
\end{tabular}

S.D.=standard deviation, HAART=highly active antiretroviral therapy, AZT=zidovudine, 3TC=lamivudine, NVP=nevirapine, TDF=tenofovi, $\mathrm{EFV}=$ efavirenz, $\mathrm{ABC}=$ abacavir, $\mathrm{Pl}=$ protease inhibitor=CD4+, cluster of differentiation, cells $/ \mu \mathrm{l}=$ cells per microliter, IQR=interquartile range
Table 3 summarizes the distribution of anaemia categorised by the patients' characteristics. Prevalence of anaemia was $79.9 \%$ in the females and $67.6 \%$ in the males, while $20.1 \%$ of the females and $32.4 \%$ of the males were non-anaemic $\left(X^{2}=6.402 ; p\right.$-value $\left.=0.011\right)$. The proportions of anaemic individuals were significantly higher among those aged $31-49$ years and 50 years and older $(78.7 \%$ and $76.3 \%$ respectively), compared to patients aged $18-30$ years, 50.0\%; (Fisher's exact test=7.501, p-value=0.023). Proportions of anaemic patients were similar; irrespective of the duration that they had been on HAART. Higher proportions of anaemic patients were found among those on zidovudine-based regimen compared to other regimens, patients who had CD4+ counts lower than 200 cells/ $\mu$ l compared to those with higher CD4+ counts, patients who were not on CPT as well as patients who had an abnormal body mass index.

We went further to conduct logistic regression, using the enter method to determine the independent relationships of different factors with anaemia. Table 4 details the bivariate analysis with crude odds ratios (COR), and the final multivariate regression model with adjusted odds ratios (AOR). Several of the patient characteristics were associated with higher odds of being anaemic on bivariate analysis. For example, the likelihood of being anaemic was $90.0 \%$ higher in the female study participants than the males, and this was statistically significant (COR= 1.90, $95 \%$ confidence interval $(\mathrm{Cl}) 1.15,3.14)$. A statistically significant association was also observed between being older than 30 years and the likelihood of being anaemic. Those aged 31 to 49 years were almost four times more likely to be anaemic $(\mathrm{COR}=3.7,95 \% \mathrm{Cl} 1.46,9.42)$ and those aged 50 years or older, three times more likely to be anaemic $(\mathrm{COR}=3.22,95 \% \mathrm{Cl} 1.23,8.42)$, compared to participants aged 18 to 30 years.

Higher odds of being anaemic was also associated with having a lesser monthly household income $(\leq 18,000$ 
Table 3 Distribution of anaemia categorised by patient characteristics

\begin{tabular}{|c|c|c|c|c|c|}
\hline \multirow{3}{*}{ Variable } & \multicolumn{4}{|c|}{ Anaemia } & \multirow{3}{*}{ p-value } \\
\hline & \multicolumn{2}{|c|}{ Present $(n=287)$} & \multicolumn{2}{|c|}{ Absent $(n=89)$} & \\
\hline & Number & $\%$ & Number & $\%$ & \\
\hline Sex of patient & & & & & 0.011 \\
\hline Female & 214 & 79.9 & 54 & 20.1 & \\
\hline Male & 73 & 67.6 & 35 & 32.4 & \\
\hline Age (years) & & & & & 0.023 \\
\hline $18-30$ & 10 & 50.0 & 10 & 50.0 & \\
\hline $31-49$ & 174 & 78.7 & 47 & 21.3 & \\
\hline 50 and older & 103 & 76.3 & 32 & 23.7 & \\
\hline Monthly household income (Naira) & & & & & 0.551 \\
\hline$\leq 18,000$ & 78 & 77.2 & 23 & 22.8 & \\
\hline$>18,000$ to $<75,000$ & 163 & 77.3 & 48 & 22.7 & \\
\hline 75,000 to $<100,000$ & 14 & 63.6 & 8 & 36.4 & \\
\hline$\geq 100,000$ & 32 & 76.2 & 10 & 23.8 & \\
\hline Duration on HAART $(n=372)$ & & & & & 0.810 \\
\hline$\leq 1$ year & 14 & 73.7 & 5 & 26.3 & \\
\hline$>1-5$ years & 61 & 79.2 & 16 & 20.8 & \\
\hline$>5$ years & 209 & 75.7 & 67 & 24.3 & \\
\hline HAART regimen $(n=372)$ & & & & & 0.373 \\
\hline $\mathrm{AZT} / 3 \mathrm{TC} / \mathrm{NVP}$ & 154 & 79.4 & 40 & 20.6 & \\
\hline TDF/3TC/EFV & 95 & 74.8 & 32 & 25.2 & \\
\hline $\mathrm{ABC} / 3 \mathrm{TC} / \mathrm{EFV}$ & 7 & 70.0 & 3 & 30.0 & \\
\hline PI-based, second line & 28 & 68.3 & 13 & 31.7 & \\
\hline 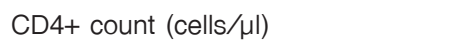 & & & & & 0.381 \\
\hline$\geq 200$ & 272 & 75.8 & 87 & 24.2 & \\
\hline$<200$ & 15 & 88.2 & 2 & 11.8 & \\
\hline On cotrimoxazole preventive therapy & & & & & 0.129 \\
\hline Yes & 94 & 71.8 & 37 & 28.2 & \\
\hline No & 193 & 78.8 & 52 & 21.2 & \\
\hline Body Mass Index & & & & & 0.272 \\
\hline Normal & 115 & 72.3 & 44 & 27.7 & \\
\hline Underweight & 3 & 60.0 & 2 & 40.0 & \\
\hline Overweight & 99 & 79.2 & 26 & 20.8 & \\
\hline Obese & 70 & 80.5 & 17 & 19.5 & \\
\hline
\end{tabular}

HAART=highly active antiretroviral therapy, AZT=zidovudine, 3TC=lamivudine, NVP=nevirapine, TDF=tenofovir, EFV=efavirenz, ABC=abacavir, $\mathrm{Pl}=$ protease inhibitor, $\mathrm{CD} 4+=$ cluster of differentiation, cells $/ \mu \mathrm{l}=$ cells per microliter

naira versus $\geq 100,000$ naira: $\mathrm{COR}=1.06,95 \% \mathrm{Cl} 0.45,2.48 ; \quad$ anaemia compared to those on $\mathrm{CPT}(\mathrm{COR}=1.46,95 \% \mathrm{Cl}$ $<75,000$ naira versus $\geq 100,000$ naira: $\mathrm{COR}=1.06,95 \% \mathrm{Cl}$ $0.49,2.31)$. Having a CD4+ count $<200$ cells/ $\mu$ l was also associated with higher odds of being anaemic (<200 cells/ $\mu \mathrm{l}$ versus $\geq 200$ cells $/ \mu \mathrm{l}: \mathrm{COR}=2.40,95 \% \mathrm{Cl} 0.54,10.70$ ). Patients not on CPT had $46.0 \%$ higher odds of being $0.91,2.34$ ). 
Table 4 Predictors of anaemia in the logistic regression model

\begin{tabular}{|c|c|c|}
\hline Variable & Crude OR & Adjusted OR \\
\hline \multicolumn{3}{|l|}{ Sex of patient } \\
\hline Male & Ref. & Ref. \\
\hline Female & $1.90(1.15-3.14)$ & $1.88(1.07-3.31)$ \\
\hline \multicolumn{3}{|l|}{ Age (years) } \\
\hline $18-30$ & Ref. & Ref. \\
\hline $31-49$ & $3.70(1.46-9.42)$ & $3.78(1.41-10.13)$ \\
\hline 50 and older & $3.22(1.23-8.42)$ & $3.79(1.36-10.55)$ \\
\hline \multicolumn{3}{|l|}{ Income per month (Naira) } \\
\hline$\geq 100,000$ & Ref. & Ref \\
\hline 75,000 to $<100,000$ & $0.55(0.18-1.68)$ & $0.43(0.13-1.38)$ \\
\hline$>18,000$ to $<75,000$ & $1.06(0.49-2.31)$ & $0.99(0.43-2.28)$ \\
\hline$\leq 18,000$ & $1.06(0.45-2.48)$ & $1.14(0.46-2.84)$ \\
\hline \multicolumn{3}{|c|}{ Duration on HAART $(\mathrm{n}=372)$} \\
\hline$\leq 1$ year & Ref. & \\
\hline$>1-5$ years & $1.36(0.43-4.34)$ & $0.99(0.28-3.51)$ \\
\hline 5 years & $1.11(0.39-3.21)$ & $0.72(0.22-2.38)$ \\
\hline \multicolumn{3}{|l|}{ HAART regimen $(n=372)$} \\
\hline AZT/3TC/NVP & Ref. & Ref. \\
\hline TDF/3TC/EFV & $0.77(0.45-1.31)$ & $0.78(0.44-1.38)$ \\
\hline $\mathrm{ABC} / 3 \mathrm{TC} / \mathrm{EFV}$ & $0.61(0.15-2.45)$ & $0.46(0.10-2.14)$ \\
\hline PI-based, second line & $0.56(0.27-1.18)$ & $0.52(0.24-1.15)$ \\
\hline \multicolumn{3}{|l|}{ 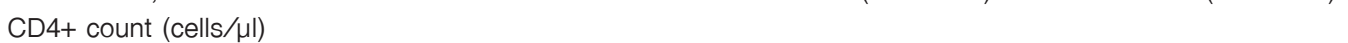 } \\
\hline$\geq 200$ & Ref. & Ref. \\
\hline$<200$ & $2.40(0.54-10.70)$ & $5.41(1.04-28.18)$ \\
\hline \multicolumn{3}{|c|}{ On cotrimoxazole preventive therapy } \\
\hline Yes & Ref. & Ref. \\
\hline No & $1.46(0.89-2.38)$ & $1.52(0.89-2.59)$ \\
\hline \multicolumn{3}{|l|}{ Body mass index } \\
\hline Normal & Ref. & Ref. \\
\hline Abnormal & $1.46(0.91-2.34)$ & $1.43(0.85-2.39)$ \\
\hline
\end{tabular}

OR=odds ratio with $95 \%$ confidence interval, Ref.=reference category, HAART=highly active antiretroviral therapy, $\mathrm{AZT}=\mathrm{zidov}$ udine, $3 \mathrm{TC}=$ lamivudine, NVP=nevirapine, TDF=tenofovir, EFV=efavirenz, ABC=abacavir, Pl=protease inhibitor, CD4+=cluster of differentiation, cells/ $\mu l=$ cells per microliter

In contrast, the odds of being anaemic were lower if the patient was on a HAART regimen other than one based on zidovudine. For instance, patients who were receiving tenofovir/amivudine/efavirenz had a 23.0\% lower likelihood of being anaemic (COR=0.77, 95\% Cl 0.45, 1.31), while those receiving abacavir/amivudine/efavirenz had even lower odds at 39.0\% (COR=0.61, 95\% Cl 0.15, 2.45). However, the association between the HAART regimen and being anaemic was not statistically significant, because the 95\% Cl spanned the null value.
Following multivariate logistic regression analysis, using the enter method, the associations between the gender of the patient and an older age with the odds of being anaemic remained statistically significant; after adjustment for other participant variables (female versus male: $\mathrm{AOR}=1.88,95 \% \mathrm{Cl} 1.07,3.31 ; 31$ to 49 years versus 18 to 30 years: $A O R=3.78,95 \% \mathrm{Cl} 1.41,10.13 ; 50$ years or older versus 18 to 30 years: $A O R=3.79,95 \% \mathrm{Cl} 1.36$, 10.55). The odds of being anaemic became accentuated in participants whose monthly household income was 18,000 
naira and below (AOR=1.14, 95\% Cl 0.46, 2.84); after adjustment for other participant variables, but not for the other income categories. This association was however not statistically significant. The odds of being anaemic also became highly accentuated among the patients who had a CD4+ count of $<200$ cells/ $\mu$ l, increasing to 5.41 (95\% Cl $1.04,28.18)$ following adjustment for other variables in the multivariate logistic regression model (Table 4).

\section{Discussion}

Anaemia is the most frequent haematological complication of HIV-1 infection ${ }^{4}$, and its treatment should begin with the treatment of the HIV infection as well as correction of the reversible causes of anaemia present in any particular patient. ${ }^{27}$ However, the multifactorial aetiology of anaemia makes it problematic when determining appropriate treatment. ${ }^{28}$ This study demonstrates a high prevalence of anaemia among the study participants; although, the majority of them had mild to moderate anaemia. This finding is likely due to the class of HAART the study participants were on. Over half of the study participants were on a zidovudine-containing HAART regimen, which has been linked to anaemia. The overall prevalence of $76.3 \%$ is consistent with results from previous studies among HIV-infected patients. ${ }^{29,30}$ It is however much higher than results reported not only by previous studies in Nigeria $^{17,19,20}$, but also in other countries. ${ }^{6,14,31,32}$ Anyabolu $^{19}$ included HAART-naïve HIV patients, while the majority of the patients in this present study were HAART-experienced and on zidovudine-containing HAART regimen, which may account for the difference in results. Prior research has demonstrated that mild to moderate anaemia is more common in HIV-positive patients than severe anaemia ${ }^{28,33}$ and this was confirmed by our study. A study among HIV-infected persons in South-West Ethiopia reported that: $72.2 \%$ of the participants had mild anaemia, $25.9 \%$ had moderate anaemia and $2.3 \%$ had severe anaemia. ${ }^{34}$
Meidani et al. ${ }^{28}$ found that $67.0 \%$ of their patients had mild to moderate anaemia, while $4.0 \%$ had severe anaemia. Similar results were observed in the north western part of Ethiopia $^{11}$ (severe anaemia, 3.0\%) and in Nepal ${ }^{31}$ (severe anaemia, 3.8\%). Ramezani and colleagues ${ }^{13}$ did not observe severe anaemia in their study.

We found that females had a higher prevalence of anaemia than men, and that in fact, gender was an independent risk factor for anaemia; with the female participants being $88.0 \%$ more likely to have anaemia than their male counterparts. It is most probably due to blood loss experienced by females during their monthly menstrual cycle, and the depletion of iron reserves during pregnancy and delivery. ${ }^{18}$ Previous research has demonstrated similar findings. ${ }^{11,35-37}$

Age was found to be a significant predictor of being anaemic in our study; those in the 31-49 years and 50 years and older age groups were 3.5 times more likely to be anaemic than patients aged 18-30 years. A similar higher prevalence of anaemia among participants aged 51 years and above was reported in Keffi, Nigeria. ${ }^{18}$ Anaemia has been shown to be independently associated with older aged HIV patients, which is attributed to the increased risk of chronic disease that comes with old age, which in addition to HIV increased the risk of anaemia. These are in addition to increasing erythropoietin resistance as well as increased pro-inflammatory cytokine expression that occurs with aging, all contributing to an occurrence of anaemia. ${ }^{14}$

Results from this study demonstrated that HAART regimens, other than a zidovudine-based regimen, were associated with lower odds of anaemia in HIV-positive patients. However, the association was not statistically significant; as seen from the $95 \% \mathrm{Cl}$ spanning the null value. Our inability to demonstrate a statistically significant relationship may likely be due to the relatively smaller numbers of patients on other HAART regimens, in comparison to those on the zidovudine-based regimen. 
Not being on CPT was associated with a higher risk of being anaemic; although this was not statistically significant. The use of CPT in HIV infected patients provides them with some protection against malaria ${ }^{38}$, a major cause of anaemia in Nigeria. In contrast, Akilimali et al. ${ }^{32}$ in Goma, Democratic Republic of Congo (DRC) found that cotrimoxazole prophylaxis was significantly associated with persistent anaemia. They attributed their findings to the high endemicity of anaemia in the DRC in association with the combined effects of malnutrition, malaria, intestinal parasites and other factors. ${ }^{32}$

Previous research has shown CD4+ counts to be a predictor of anaemia..$^{19,28,34}$ In our study, HIV infected patients who had CD4+ counts $<200$ cells/ $\mu$ l were almost five times more likely to be anaemic than those with higher CD4+ counts, but this association was not statistically significant. This may be due to the small proportion of patients whose CD4+ count was $<200$ cells/ $\mu$ l (4.5\%). The majority of our patients were on HAART and had high CD4+ counts, which indicated good adherence to their ARV medications. Our finding corroborates previous research that found no significant association between CD4+ count and anaemia. ${ }^{18,23}$

This study is limited by its cross-sectional design, which prevents definite establishment of the temporal relationship between anaemia and its associated factors. ${ }^{37}$ Furthermore, because we included only out-patients the findings may therefore not be generalizable to hospitalised HIV-infected patients. Also, laboratory assessment of anaemia was based only on haemoglobin levels in the blood, without morphological assessment of red blood cells using peripheral blood films. Morphological classification of anaemia based on the mean corpuscular volume as either microcytic, normocytic or macrocytic is valuable in determining the aetiology of anaemia; especially in cases of moderate-severe anaemia. Microcytic anaemia is most commonly caused by iron-deficiency anaemia; other important causes include sickle cell disease, thalassaemia and other haemoglobinopathies. Normocytic anaemia may reflect early stages of microcytic or macrocytic anaemia, but is commonly caused by acute blood loss, chronic inflammation or may be an early manifestation of a systemic disorder; such as renal disease or cancer. Macrocytic anaemia is typical of folic acid and/or vitamin B12 deficiency. Other important causes include: alcohol abuse, liver disease, hypothyroidism, use of certain medications; such as methotrexate, that inhibit nucleic acid metabolism. ${ }^{39}$

\section{Conclusion}

This study on anaemia, immune status and use of HAART in HIV infected patients demonstrated a high prevalence of anaemia among adult HIV infected patients. The care of this sub-group of the population should therefore include laboratory screening for anaemia at diagnosis of HIV infection, and at regular follow-up intervals, so as to enhance early detection and correction, in order to improve their quality of life. The study findings also demonstrated that an older age and being female were significant predictors of anaemia in HIV infected patients. More than half of the study participants were on a zidovudine-based regimen, which was associated with higher odds of having anaemia compared to other regimens. These findings therefore call for close monitoring for anaemia; especially in women who have the added risk that comes with their gender, ${ }^{28}$ in older patients as well as patients on zidovudine-based regimens. There is also the need for increased access in this population to other first-line HAART regimens that are less toxic to the haematological system; such as, those based on tenofovir and abacavir. ${ }^{36}$

\section{Acknowledgement}

The authors are grateful to the patients of the Adult ART clinic, NAUTH Nnewi, who participated in this study. 


\section{Funding sources}

This research was self-funded by the authors.

\section{Conflict of interest}

There are no potential conflicts of interest to declare.

\section{References}

1. World Health Organisation. Haemoglobin concentrations for the diagnosis of anaemia and assessment of severity. Vitamin and Mineral Nutrition Information System [monograph on the Internet] Geneva: WHO; 2011 [cited 2020 Apr 27]. Available from: http:// www.who.int/vmnis/indicators/haemoglobin.pdf

2. Kassebaum NJ, Jasrasaria R, Naghavi M, Wulf SK, Johns N, Lozano $\mathrm{R}$ et al. A systematic analysis of global anemia burden from 1990 to 2010. Blood 2014;123:615-24.

3. Fauci AS, Lane HC. Human immunodeficiency virus disease: AIDS and related disorders. In: Kasper DL, Fauci AS, Hauser SL, Longo DL, Jameson JL, Loscalzo J, editors. Harrison's principles of internal medicine. $19^{\text {th }}$ ed. New York: McGraw Hill Education; 2015;p.1215-85.

4. Takuva S, Maskew M, Brennan AT, Sanne I, Macphail AP, Fox MP. Anemia among HIV infected patients initiating antiretroviral therapy in South Africa: improvement in hemoglobin regardless of degree of immunosuppression and the initiating ART Regimen. J Trop Med 2013;2013:1-6.

5. Obirikorang C, Yeboah FA. Blood haemoglobin measurement as a predictive indicator for the progression of HIV/AIDS in resource-limited setting. J Biomed Sci 2009;16:102.

6. Masaisa F, Gahutu JB, Mukiibi J, Delanghe J, Philippé J. Anaemia in human immunodeficiency virus-infected and uninfected women in Rwanda. Am J Trop Med Hyg 2011;84: 456-60.

7. Petraro P, Duggan C, Spiegelman D, Hertzmark E, Makubi A, Chalamilla G, et al. Determinants of anemia among human immunodeficiency virus-positive adults at care and treatment clinics in Dar es Salaam, Tanzania. Am J Trop Med Hyg 2016; 94:384-92.

8. Redig AJ, Berliner N. Pathogenesis and clinical implications of HIV-related anemia in 2013. Hematology 2013;2013:377-81.

9. Mugisha JO, Shafer LA, Van Der Paal L, Mayanja BN, Eotu $\mathrm{H}$, Hughes $\mathrm{P}$ et al. Anaemia in a rural Ugandan HIV cohort: prevalence at enrolment, incidence, diagnosis and associated factors. Trop Med Int Health 2008;13:788-94.

10. Santosh N, Rachita VG, Sindhoora K, Jagadish C. Clinical profile of among HIV infected patients and its correlation with CD4+ count. J Evol Med Dent Sci 2015;4:10795-802.

11. Ferede G, Wondimeneh Y. Prevalence and related factors of anemia in HAART-naïve HIV positive patients at Gondar University Hospital, Northwest Ethiopia. BMC Hematol 2013; 13:8.

12. World Health Organisation. Interim WHO clinical staging of HIV/AIDS and HIV/AIDS case definition for surveillance, African region [monograph on the Internet]. Geneva: WHO; 2005 [cited 2020 Apr 16]. Available from: https://www.who.int/hiv/pub/ guidelines/clinicalstaging.pdf?ua=1

13. Ramezani A, Aghakhani A, Sharif MR, Banifazl M, Eslamifar A, Velayati AA. Anaemia prevalence and related factors in HIV-related patients: A cohort study. Iran J Pathol 2008;3:125-8.

14. Assefa M, Abegaz WE, Shewamare A, Medhin G, Belay M. Prevalence and correlates of anemia among HIV infected patients on highly active anti-retroviral therapy at Zewditu Memorial Hospital, Ethiopia. BMC Hematol 2015;15:6.

15. Harris RJ, Sterne JAC, Abgrall S, Dabis Francois, Reiss P, Saag Michael et al. Prognostic importance of anaemia in HIV-1 infected patients starting antiretroviral therapy: collaborative analysis of prospective cohort studies in industrialized countries. Antivir Ther 2008;13:959.

16. Kerkhoff AD, Wood R, Cobelens FG, Gupta-Wright A, Bekker L, Lawn SD. Resolution of anaemia in a cohort of HIV-infected patients with a high prevalence and incidence of tuberculosis receiving antiretroviral therapy in South Africa. BMC Infect Dis $2014 ; 14: 3860$.

17. Denue BA, Kida IM, Hammagabdo A, Dayar A, Sahabi MA. Prevalence of anemia and immunological markers in HIV infected patients on highly active antiretroviral therapy in northeastern Nigeria. Infect Dis Res Treat 2013;6:25-33.

18. Pennap GR, Abubakar K. Prevalence of anemia among human immunodeficiency virus infected patients accessing healthcare in Federal Medical Center Keffi. Int J Trop Dis Health 2015; 10:1-7.

19. Anyabolu E. Prevalence and associated factors of anemia in treatment-naïve HIV-positive subjects in southeast Nigeria. Am J Med Sci Med 2016;4:41-6. 
20. Omoregie R, Omokaro EU, Palmer O, Ogefere HO, Egbeobauwaye A, Adegue JE, et al. Prevalence of anaemia among HIV infected patients in Benin city, Nigeria. Tanzan J Health Res 2009;11:1-4.

21. Munyazesa E, Emile I, Mutimura E, Hoover DR, Shi Q, McGinn $\mathrm{AP}$, et al. Assessment of haematological parameters in HIV infected and uninfected Rwandan women: a cross-sectional study. BMJ Open 2012;2:e001600.

22. Mata-marín JA, Gaytán-martínez JE, Martínez-martínez RE, Arroyo-anduiza $\mathrm{Cl}$, Fuentes-allen JL, Casarrubias-ramirez M. Risk factors and correlates for anemia in HIV treatment-naïve infected patients: a cross-sectional analytical study. BMC Res Notes 2010;3:230.

23. Adewumi AA, Akinsegun AA, Titilope AA, Osamuedemen VA, Vincent OO, Dapus OD et al. Prevalence of HIV-related autoimmune haemolytic anaemia in Lagos, Nigeria. Niger Med $J$ 2014;55:63-6.

24. Cochran WG. Sampling techniques. $3^{\text {rd }}$ ed. New York: John Wiley \& Sons; 1977.

25. Dayyal DG. Cyanmethemoglobin (hemoglobin-cyanide) method for estimation of hemoglobin [monograph on the Internet]. Bioscience PK; 2016 [cited 2020 Jan 24]. Available from: https:// www.bioscience.com.pk/topics/cell-biology/item/167cyanmethemoglobin-hemoglobin-cyanide-method-forestimation-of-hemoglobin

26. Federal Ministry of Health. National guidelines for HIV prevention, treatment and care [monograph on in Internet]. Abuja: National AIDS and STIs control programme; 2016 [cited 2020 Jan 24]. Available from: http://apps.who.int/medicinedocs/documents/ s23252en.pdf

27. Friel TJ, Scadden DT. Hematologic manifestations of HIV infection: anemia. Uptodate [homepage on the Internet]. Alpen aan den Rijn: Wolters Kluwer; 2017 [cited 2017 Dec 18]. Available from: http://www.uptodate.com/contents/hematologicmanifestations-of-hiv-infection-anemia.

28. Meidani M, Rezaei F, Maracy MR, Avijgan M, Tayeri K. Prevalence, severity, and related factors of anemia in HIV/AIDS patients. J Res Med Sci 2012;17:138-142.

29. Gunda DW, Kilonzo SB, Mpondo BC. Magnitude and correlates of moderate to severe anemia among adult HIV patients receiving first line HAART in northwestern Tanzania: A cross sectional clinic based study. Pan Afr Med J 2016;23:1-6.

30. Chandrakar J, Siddiqui R. Haematological profile of HIV sero- positive patients in relation to CD4+ lymphocyte count. J Evid based Med Healthc 2015;2:6399-405.

31. Martin C, Poudel-Tandukar K, Poudel KC. HIV Symptom burden and anemia among HIV-positive individuals: cross-sectional results of a community-based positive living with HIV (POLH) study in Nepal. PloS One 2014;9:e116263.

32. Akilimali PZ, Kashala-Abotnes E, Musumari PM, Kayembe PK, Tylleskar T, Mapatano MA. Predictors of persistent anaemia in the first year of antiretroviral therapy: a retrospective cohort study from Goma, the Democratic Republic of Congo. PloS One 2015; 10:e0140240.

33. Lai JL, Chen YH, Liu YM, Yuan JJ, Lin J, Huang AQ et al. Prevalence and risk factors of anaemia in hospitalised HIV-infected patients in southeast China: a retrospective study. Epidemiol Infect 2019;147:e81.

34. Gedefaw L, Yemane T, Sahlemariam Z, Yilma D. Anemia and risk factors in HAART naïve and HAART experienced HIV positive persons in South West Ethiopia: a comparative study. PloS One 2013;8:e72202.

35. Melese H, Wassie MM, Woldie H, Tadesse A, Mesfin N. Anemia among adult HIV patients in Ethiopia: a hospital-based crosssectional study. HIV/AIDS - Res Palliat Care 2017;9:25-30.

36. Owiredu WKBA, Quaye L, Amidu N, Addai-Mensa O. Prevalence of anaemia and immunological markers among Ghanaian HAART-naïve HIV-patients and those on HAART. Afr Health Sci 2011;11:2-15.

37. Subbaraman R, Devaleenal B, Selvamuthu P, Yepthomi T, Solomon SS, Mayer KH, et al. Factors associated with anaemia in HIV infected individuals in Southern India. Int J STD AIDS 2009;20:489-92.

38. World Health Organisation. Guidelines on post-exposure prophylaxis for HIV and the use of cotrimoxazole prophylaxis for HIV-related infections among adults, adolescents and children. Recommendations for a public health approachDecember 2014 supplement to the 2013 consolidated ARV guidelines [monograph on the Internet]. Geneva: WHO; 2014 [cited 2020 Apr 16]. Available from: http://www.who.int/hiv/pub/ guidelines/arv2013/arvs2013upplment_dec2014/en

39. Smeeton B, Norton B, Belete S, Singh A. Haematology: anemia overview notes. Pulsenotes [serial on the Internet]. 2020 [cited 24 Oct 2020]. Available from: https://app.pulsenotes. $\mathrm{com} /$ medicine/haematology/notes/anaemia-overview 